\title{
Pengaruh Jenis Prebiotik terhadap Kualitas Yogurt Probiotik
}

\author{
Influence of Prebiotics Variety on the Quality of Probiotic Yogurt
}

Ekawati Purwijantiningsih

Fakultas Teknobiologi, Universitas Atma Jaya Yogyakarta, Yogyakarta 55281

E-mail: e_purwiyanti@yahoo.com

\begin{abstract}
Prebiotics are variety of nondigestible carbohydrates that help promote the growth of good bacteria in the intestines. Prebiotics are found naturally in legumes, vegetables, fruits and tubers. Soybean, banana and tapioca are supposed to have potential as prebiotics, promote a healthy digestive system and reduce the growth of harmful bacteria. Soybean, banana and tapioca were investigated on their abilities to promote the quality of probiotic yogurt. Soybean flour addition to probiotic yogurt most potential to promote nutrition value and lactic acid bacteria viability. The most preference of probiotic yogurt by panelists is probiotic yogurt added tapioca.
\end{abstract}

Key words: prebiotics, probiotics, lactic acid bacteria, yogurt

Diterima: 14 Maret 2007, disetujui: 27 Juli 2007

\section{Pendahuluan}

Prebiotik adalah karbohidrat kompleks yang tidak dapat dicerna oleh saluran pencernaan dan dapat menstimulasi pertumbuhan bakteri menguntungkan dalam usus manusia. Prebiotik secara alami dapat ditemukan pada biji-bijian, sayuran, buahbuahan, dan umbi-umbian. Secara umum prebiotik bermanfaat bagi kesehatan dengan cara memberi nutrisi khusus bagi bakteri yang menguntungkan, sehingga meningkatkan jumlah bakteri yang menguntungkan dan mengurangi jumlah bakteri merugikan di dalam usus manusia (Waspodo, 2002).

Beberapa prebiotik yang mengandung fruktosa seperti inulin dan fruktooligosakarida diketahui mampu mengubah komposisi mikroflora dalam sistem pencernaan ke arah dominasi Bifidobacterium. Hal tersebut yang disebut dengan efek bifidogenik (Fook et al., 1999).

Bakteri probiotik yang sudah melalui uji klinis diantaranya adalah Lactobacillius casei subsp. casei Shirota strain yang terdapat dalam yakult, Bifidobacterium dan Lactobacillus acidophilus (Waspodo, 2002; Triana \& Nurhidayat, 2007). Bakteri yogurt yaitu $L$. bulgaricus dan Streptococcus thermophillus tidak termasuk bakteri probiotik. Yogurt biasanya ditambah L. acidophilus, agar mempunyai efek fungsional bagi kesehatan. Yogurt yang sudah ditambah bakteri probiotik dapat dikatakan sebagai yogurt probiotik (Waspodo, 2002).

Kualitas yogurt probiotik yang baik yaitu bila selama masa simpan masih mengandung bakteri probiotik yang hidup sehingga bila dikonsumsi bakteri tersebut dapat hidup pada usus besar (Widodo \& Soeparno, 2002). Selain itu kualitas yogurt dikatakan baik apabila memenuhi syarat mutu berdasarkan SNI 012981 (1992).

Pada penelitian ini jenis prebiotik yang akan ditambahkan pada yogurt probiotik adalah tepung tapioka, tepung kedelai serta tepung pisang. Ketiga jenis komoditi tersebut murah dan mudah didapat dan berdasarkan beberapa pustaka diduga berpotensi sebagai sumber prebiotik, tetapi kajian lebih lanjut tentang hal tersebut masih jarang dilakukan. 
Penelitian ini bertujuan untuk mengetahui pengaruh jenis prebiotik terhadap kualitas yogurt probiotik yang dihasilkan dan viabilitas bakteri asam laktat selama masa simpan serta mengetahui jenis prebiotik yang paling berpotensi untuk meningkatkan kualitas yogurt probiotik.

\section{Metode Penelitian}

\section{Bahan}

Bahan yang digunakan adalah bakteri yogurt Lactobacillus bulgarius FNCC040 dan Streptococcus thermophilus FNCC041 serta bakteri probiotik Lactobacillus acidophilus FNCC0051 yang diperoleh dari Pusat Studi Pangan dan Gizi UGM. Tepung tapioka, pisang dan kedelai yang digunakan berasal dari Pasar Gowok, Yogyakarta, susu skim bubuk, susu skim cair, laktosa cair, medium MRS, SCB (Selenite Cystein Broth), BGLB (Brillian Green Lactosa Bile Broth), medium SSA (Salmonella Shigella Agar), akuades, alkohol, $\mathrm{H}_{2} \mathrm{SO}_{4}, \mathrm{NaOH}$, indikator $\mathrm{PP}, \mathrm{K}_{2} \mathrm{SO}_{4}-\mathrm{CuSO}_{4}$, $\mathrm{HCl}$, petroleum eter, ammonia pekat.

\section{Rancangan percobaan dan analisis data}

Rancangan percobaan yang digunakan pada penelitian ini adalah Rancangan Acak Lengkap faktorial. Faktor pertama yaitu variasi jenis prebiotik dan faktor kedua adalah waktu penyimpanan. Data yang diperoleh dianalisis dengan ANOVA. Selanjutnya untuk mengetahui letak beda nyata dilakukan uji DMRT.

\section{Cara Kerja}

Tahapan penelitian yang dilakukan adalah: pembuatan tepung kedelai dan tepung pisang, pembuatan starter, fermentasi yogurt probiotik dan analisis parameter kualitas yogurt probiotik.

\section{Pembuatan starter yogurt probiotik}

Pembuatan starter yogurt probiotik mengunakan cara Dave dan Shah (1997). Larutan susu skim 5\% sebanyak $10 \mathrm{ml}$ disterilisasi pada suhu $115^{\circ} \mathrm{C}$ selama 15 menit. Susu kemudian didinginkan dan diinokulasi dengan Lactobacillus bulgaricus, L. acidophilus dan Streptococcus thermophilus secara terpisah masing-masing $1 \mathrm{ml}$. Susu yang diinokulasi dengan ke-tiga bakteri diinkubasi pada suhu $30-37^{0} \mathrm{C}$ selama 24 jam.

\section{Fermentasi yogurt probiotik}

Demikian juga fermentasi yogurt probiotik juga menggunakan cara Dave dan Shah (1997). Susu skim cair sebanyak $500 \mathrm{ml}$ ditambah $4 \%$ susu skim bubuk dan $4 \%$ prebiotik (sesuai perlakuan). Susu dipasteurisasi pada suhu $90^{\circ} \mathrm{C}$ selama 15 menit, selanjutnya didinginkan sampai suhu kira-kira $40-45^{\circ} \mathrm{C}$ dan diinokulasi dengan $6 \%(\mathrm{v} / \mathrm{v})$ starter yang terdiri atas 2\% Streptococcus thermophilus, 2\% Lactobacillus bulgaricus dan 2\% Lactobacillus acidophilus. Fermentasi dilakukan pada suhu $42^{0} \mathrm{C}$ selama 5 jam.

Analisis parameter kualitas yogurt probiotik meliputi viabilitas bakteri asam laktat (Dave \& Shah, 1997), pH, kadar asam laktat (AOAC, 1990), kadar protein (Sudarmadji et al., 1989), kadar lemak (Budiharta, 1992), kadar serat (Anggorodi, 1979), uji Coliform dan Salmonella (Rahayu, 2003). Selain itu dilakukan uji organoleptik yang meliputi warna, aroma dan tekstur untuk mengetahui penerimaan konsumen (Kartika et al., 1987). Panelis yang terlibat dalam uji organoleptik sebanyak 30 orang. Skor yang digunakan berkisar antara 1- 4 . Angka 1 = tidak suka, $2=$ agak suka, 3 = suka, dan 4 = sangat suka.

\section{Hasil dan Pembahasan}

\section{Viabilitas bakteri asam laktat}

Viabilitas sel bakteri asam laktat dalam produk susu fermentasi penting artinya mengingat adanya efek menguntungkan dari keberadaan sel tersebut bagi kesehatan. Menurut Salminen dan Wright (1993), syarat minuman probiotik mengandung lebih dari $10^{8}$ sel bakteri probiotik per mililiter dalam keadaan hidup. Jumlah rata-rata bakteri asam laktat yang terdapat pada yogurt probiotik selama penyimpanan hari ke 0 sampai hari ke 40 berkisar antara 10,32 - $12.57 \log \mathrm{cfu} / \mathrm{ml}$. Hasil analisis varian menunjukkan bahwa jenis prebiotik dan waktu penyimpanan berpengaruh 
terhadap viabilitas bakteri asam laktat (Tabel 1).

Viabilitas bakteri asam laktat tertinggi terdapat pada yogurt probiotik dengan penambahan tepung kedelai. Menurut Yusmarini et al., (1998) kedelai mengandung rafinosa dan stakiosa relatif tinggi. Lactobacillus acidophilus dan Streptococcus thermophilus memiliki enzim $\alpha$-galaktosidase yang dapat menghidrolisis ikatan $\alpha-1-6$ galaktosida sehingga dapat memanfaatkan oligosakarida tersebut untuk pertumbuhannya.

Selama penyimpanan sampai hari ke 30 , jumlah bakteri asam laktat terus mengalami peningkatan, tetapi pada penyimpanan hari ke 40 jumlah bakteri asam laktat menurun
(Gambar 1), walaupun jumlah tersebut masih memenuhi kriteria syarat minuman probiotik yakni harus mengandung lebih dari $10^{8}$ sel bakteri probiotik per ml.

Selain menghasilkan asam laktat, bakteri asam laktat juga menghasilkan metabolit lain seperti hidrogen peroksida dan senyawa antibiotik lain yang selain dapat menghambat pertumbuhan bakteri patogen, dalam akumulasi yang besar dimungkinkan menghambat bakteri asam laktat juga (Suseno et al., 2000). Penurunan jumlah bakteri asam laktat juga dapat disebabkan oleh berkurangnya nutrisi bagi bakteri asam laktat (Tamime \& Deeth, 1989).

Tabel 1. Viabilitas bakteri asam laktat (log $\mathrm{cfu} / \mathrm{ml}$ ) yogurt probiotik dengan variasi jenis prebiotik selama masa simpan

\begin{tabular}{|c|c|c|c|c|c|c|}
\hline \multirow{2}{*}{ Jenis Prebiotik } & \multicolumn{5}{|c|}{$\begin{array}{l}\text { Umur Simpan (Hari Ke-) } \\
\end{array}$} & \multirow{2}{*}{ Rata-rata } \\
\hline & $\mathbf{0}$ & 10 & 20 & 30 & 40 & \\
\hline Kontrol & 10.51 & 10.72 & 11.71 & 11.89 & 11.32 & $11.23^{\mathrm{A}}$ \\
\hline Kedelai & 10.69 & 11.58 & 11.94 & 12.57 & 11.48 & $11.65^{\mathrm{B}}$ \\
\hline Pisang & 10.32 & 10.82 & 11.84 & 11.69 & 11.37 & $11.21^{\mathrm{A}}$ \\
\hline Tapioka & 10.32 & 10.69 & 11.45 & 11.42 & 11.21 & $11.02^{\mathrm{A}}$ \\
\hline Rata-rata & $1.46^{\mathrm{A}}$ & $10.95^{\mathrm{B}}$ & $11.74^{\mathrm{CD}}$ & $11.89^{\mathrm{D}}$ & $11.35^{\mathrm{BC}}$ & \\
\hline
\end{tabular}

Keterangan: angka yang diikuti huruf yang sama tidak beda nyata pada taraf kepercayaan 95\%

Tabel 2. Perubahan $\mathrm{pH}$ yogurt probiotik dengan variasi jenis prebiotik selama masa simpan

\begin{tabular}{|c|c|c|c|c|c|c|}
\hline \multirow{2}{*}{ Jenis Prebiotik } & \multicolumn{5}{|c|}{ Umur simpan (hari ke-) } & \multirow{2}{*}{ Rata-rata } \\
\hline & $\mathbf{0}$ & 10 & 20 & 30 & 40 & \\
\hline "Kontrol & 5.73 & 5.57 & 5.53 & 5.53 & 5.40 & $5.55^{\mathrm{D}}$ \\
\hline Kedelai & 5.03 & 5.00 & 4.97 & 4.83 & 4.53 & $4.87^{\mathrm{A}}$ \\
\hline Pisang & 5.13 & 5.20 & 5.10 & 4.93 & 4.83 & $5.06^{\mathrm{B}}$ \\
\hline Tapioka & 5.47 & 5.53 & 5.50 & 5.20 & 5.03 & $5.39^{\mathrm{C}}$ \\
\hline Rata-rata & $5.34^{\mathrm{C}}$ & $5.33^{\mathrm{C}}$ & $5.28^{\mathrm{BC}}$ & $5.14^{\mathrm{AB}}$ & $5.03^{A}$ & \\
\hline
\end{tabular}

Keterangan: angka yang diikuti huruf yang sama tidak beda nyata pada taraf kepercayaan 95\%

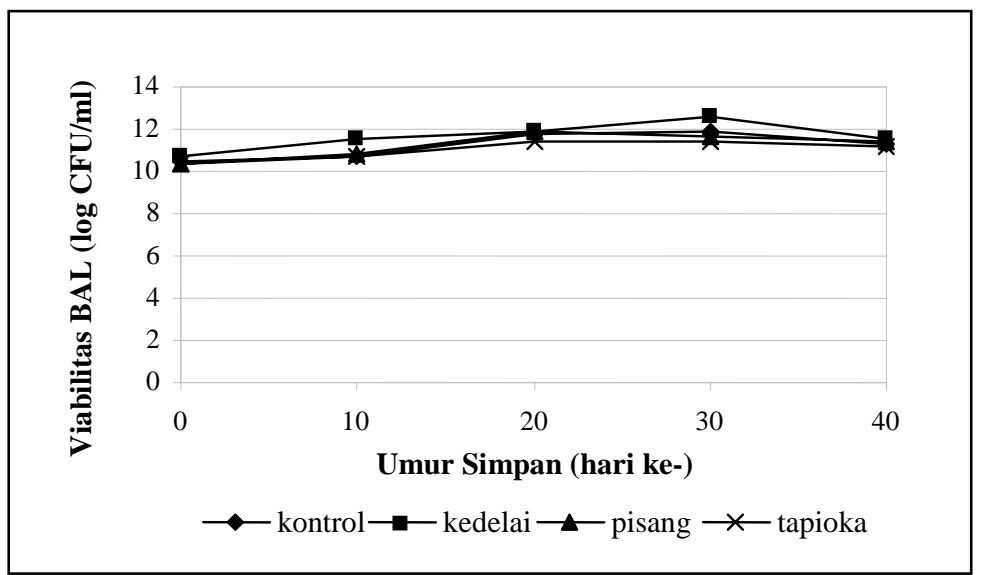

Gambar 1. Viabilitas BAL yogurt probiotik dengan variasi jenis prebiotik selama masa simpan 


\section{Penurunan pH}

Derajat keasaman rata-rata yogurt probiotik setelah diinkubasi dan disimpan dalam refrigerator selama 40 hari berkisar antara 4.53 - 5.73. Hasil analisis varian menunjukkan bahwa jenis prebiotik dan waktu penyimpanan berpengaruh terhadap $\mathrm{pH}$ yogurt probiotik (Tabel 2).

Dihasilkannya asam laktat sebagai hasil metabolisme gula menyebabkan penurunan $\mathrm{pH}$ yogurt probiotik. $\mathrm{pH}$ akan semakin menurun dari hari ke 0 sampai hari ke 40 (Gambar 2). Hal tersebut berkaitan dengan semakin meningkatnya jumlah bakteri asam laktat yang akan menggunakan laktosa untuk diubah menjadi asam laktat yang menyebabkan penurunan $\mathrm{pH}$.

Derajat keasaman yogurt probiotik terendah dihasilkan dari perlakuan yogurt probiotik yang ditambahkan prebiotik tepung kedelai. Pada yogurt probiotik dengan penambahan tepung kedelai dijumpai bakteri asam laktat dalam jumlah paling besar sehingga asam laktat yang dihasilkan akan semakin banyak dan menyebabkan $\mathrm{pH}$ paling rendah.

\section{Asam laktat}

Selama berlangsung fermentasi susu menjadi yogurt, laktosa dalam susu akan diubah menjadi asam laktat oleh bakteri asam laktat. Laktosa digunakan sebagai sumber karbon untuk pertumbuhan maupun sebagai sumber energi. Laktosa dalam susu ditransfer ke dalam sel oleh enzim permease, kemudian oleh enzim laktase atau phospho-galaktosidase (p-gal) diubah menjadi galaktosa dan glukosa. Glukosa yang terbentuk, selanjutnya oleh bakteri asam laktat dimetabolisme menjadi asam laktat (Tamime \& Deeth, 1989).

Hasil analisis varian menunjukkan bahwa jenis prebiotik dan waktu penyimpanan berpengaruh terhadap kadar asam laktat yogurt probiotik. Rata-rata asam laktat yang terbentuk pada yogurt probiotik berkisar antara 0.852.28\% (Tabel 3). Kandungan asam laktat yang disyaratkan menurut SNI berkisar antara 0.5 2.0\%. Berdasarkan Gambar 3 terlihat bahwa selama penyimpanan terjadi kenaikan kadar asam laktat tetapi mengalami penurunan pada hari ke 40, kecuali pada yogurt probiotik dengan penambahan tepung kedelai.

Tabel 3. Perubahan kadar asam laktat (\%) yogurt probiotik dengan variasi jenis prebiotik selama masa simpan

\begin{tabular}{ccccccc}
\hline \hline \multirow{2}{*}{ Jenis Prebiotik } & \multicolumn{9}{c}{ Umur Simpan (Hari Ke-) } & \multirow{2}{*}{ Rata-rata } \\
\cline { 2 - 5 } & $\mathbf{0}$ & $\mathbf{1 0}$ & $\mathbf{2 0}$ & $\mathbf{3 0}$ & $\mathbf{4 0}$ & \\
\hline \hline Kontrol & 0.85 & 0.92 & 1.40 & 1.47 & 1.24 & $1.12^{\mathrm{A}}$ \\
Kedelai & 0.97 & 1.13 & 1.56 & 2.12 & 2.28 & $1.68^{\mathrm{C}}$ \\
Pisang & 0.89 & 1.03 & 1.47 & 2.12 & 1.74 & $1.42^{\mathrm{B}}$ \\
Tapioka & 0.92 & $0.97^{\mathrm{AB}}$ & 1.39 & 1.66 & 1.50 & $1.27^{\mathrm{AB}}$ \\
\hline \hline Rata-rata & $0.83^{\mathrm{A}}$ & $1.01^{\mathrm{A}}$ & $1.45^{\mathrm{B}}$ & $1.87^{\mathrm{C}}$ & $1.69^{\mathrm{BC}}$ & \\
\hline \hline
\end{tabular}

Keterangan: angka yang diikuti huruf yang sama tidak beda nyata pada taraf kepercayaan 95\%

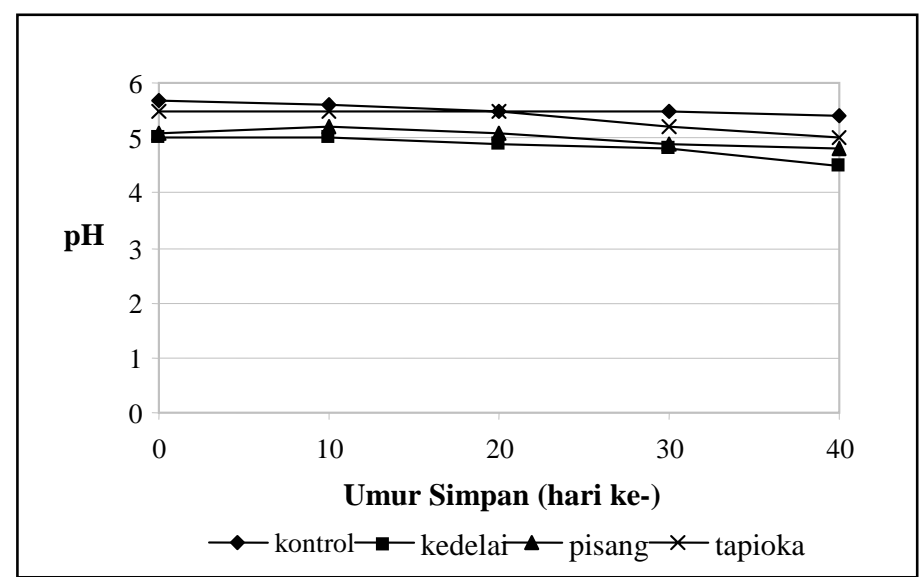

Gambar 2. Penurunan $\mathrm{pH}$ yogurt probiotik dengan variasi jenis prebiotik selama masa simpan 
Kadar asam laktat tertinggi dihasilkan pada yogurt probiotik dengan penambahan tepung kedelai. Pada yogurt probiotik dengan penambahan tepung kedelai dijumpai bakteri asam laktat dalam jumlah paling besar sehingga asam laktat yang dihasilkan juga semakin banyak.

\section{Kadar protein}

Menurut Murti (2006), protein yogurt dicerna dua kali lebih cepat dari susu yang tidak difermentasi, demikian pula penyerapannya. Hal tersebut tidak terlepas dari kasein yang menggumpal itu mempunyai partikel yang lebih kecil. Protein dalam keadaan asam merangsang kerja enzim pepsin sehingga memperbaiki daya cerna.

Kadar protein yogurt probiotik yang dihasilkan berkisar antara $3.60-4.21 \%$. Kadar protein tertinggi yaitu sebesar $4.21 \%$ terdapat pada yogurt probiotik yang ditambahkan tepung kedelai (Tabel 4). Hal tersebut disebabkan karena kandungan protein kedelai paling tinggi (42.28\%) dibandingkan prebiotik lainnya yaitu tapioka (1.16\%) dan pisang (3.05\%). Semua yogurt probiotik yang dihasilkan memiliki kandungan protein yang disyaratkan SNI yaitu minimal 3.5\%.

Hasil analisis varian menunjukkan bahwa jenis prebiotik berpengaruh terhadap kadar protein. Kadar protein mengalami penurunan sampai dengan hari ke 20, tetapi pada hari ke 30 kadar protein mengalami peningkatan, walaupun secara statistik tidak berbeda nyata (Gambar 4).

Penurunan dan peningkatan kadar protein pada sampel dipengaruhi oleh aktivitas bakteri asam laktat. Bakteri asam laktat memiliki sifat proteolitik, hal ini terkait dengan kemampuannya menggunakan protein susu sebagai sumber N (Gilliand, 1985), sehingga kadar protein menurun. Penurunan dan peningkatan kadar protein berkaitan juga dengan adanya bakteri asam laktat yang hidup pada yogurt karena pada saat pengukuran protein diduga protein bakteri asam laktat juga ikut terukur.

Tabel 4. Perubahan kadar protein (\%) yogurt probiotik dengan variasi jenis Prebiotik selama masa simpan

\begin{tabular}{|c|c|c|c|c|c|c|}
\hline \multirow{2}{*}{ Jenis Prebiotik } & \multicolumn{5}{|c|}{ Umur Simpan (Hari Ke-) } & \multirow{2}{*}{ Rata-rata } \\
\hline & $\mathbf{0}$ & 10 & 20 & 30 & 40 & \\
\hline Kontrol & 3.79 & 3.62 & 3.59 & 3.63 & 3.60 & $3.65^{\mathrm{A}}$ \\
\hline Kedelai & 4.21 & 3.99 & 3.95 & 3.99 & 3.91 & $4.01^{\mathrm{B}}$ \\
\hline Pisang & 3.85 & 3.71 & 3.68 & 3.90 & 3.80 & $3.79^{\mathrm{A}}$ \\
\hline Tapioka & 3.75 & 3.66 & 3.66 & 3.87 & 3.74 & $3.74^{\mathrm{A}}$ \\
\hline Rata-rata & $3.90^{\mathrm{A}}$ & $3.74^{\mathrm{A}}$ & $3.72^{\mathrm{A}}$ & $3.85^{\mathrm{A}}$ & $3.77^{\mathrm{A}}$ & \\
\hline
\end{tabular}

Keterangan: angka yang diikuti huruf yang sama tidak beda nyata pada taraf kepercayaan 95\%

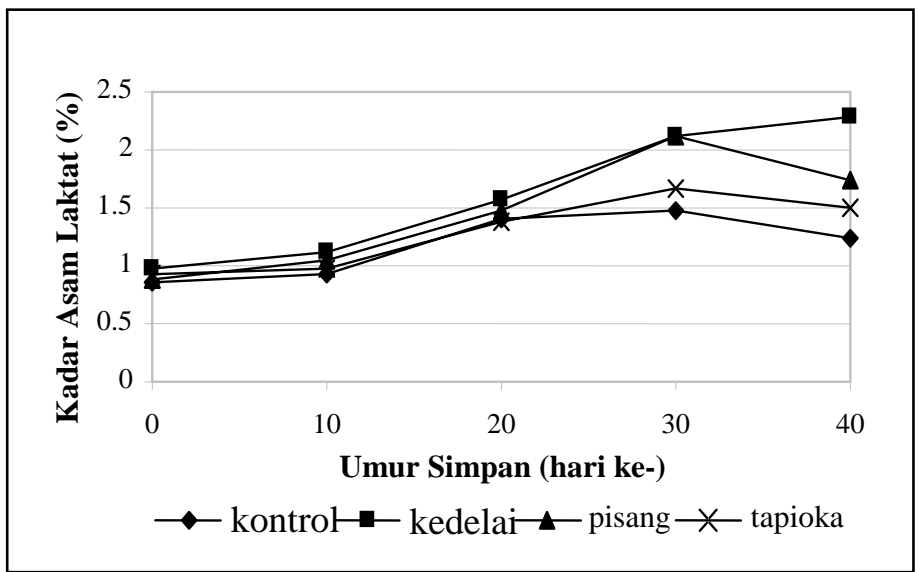

Gambar 3. Kadar asam laktat (\%) yogurt probiotik dengan variasi jenis prebiotik selama masa simpan 


\section{Kadar lemak}

Lemak pada susu merupakan komponen penting dalam pembentukan flavor gurih pada susu (Buckle et al., 1987). Kadar lemak yogurt probiotik yang dihasilkan berkisar antara 0.23 - 2.43\% (Tabel 5). Kadar lemak tertinggi terdapat pada yogurt probiotik yang ditambahkan tepung kedelai. Hal tersebut disebabkan karena kandungan lemak kedelai paling tinggi (22.54\%) dibandingkan prebiotik lainnya yakni tapioka (0.51\%) dan pisang $(0.28 \%)$. Semua yogurt probiotik yang dihasilkan memiliki kandungan lemak yang disyaratkan SNI yaitu maksimal 3.8\%.

Kadar lemak mengalami penurunan sampai hari ke 30 (Gambar 5). Penurunan lemak akibat aktivitas bakteri asam laktat yang memiliki enzim lipase yang berfungsi untuk mendegradasi lemak (Tamime \& Deeth, 1989). Pada hari ke 40 kadar lemak meningkat, karena pada hari ke 40 terjadi penurunan jumlah bakteri asam laktat menyebabkan aktivitas enzim lipase menurun. Pada saat pengukuran kadar lemak, diduga lemak dari bakteri asam laktat juga terukur.

Tabel 5. Perubahan kadar lemak (\%) yogurt probiotik dengan variasi jenis Prebiotik selama masa simpan

\begin{tabular}{ccccccc}
\hline \hline \multirow{2}{*}{ Jenis Prebiotik } & \multicolumn{9}{c}{ Umur Simpan (Hari Ke-) } & \multirow{2}{*}{ Rata-rata } \\
\cline { 2 - 6 } & $\mathbf{0}$ & $\mathbf{1 0}$ & $\mathbf{2 0}$ & $\mathbf{3 0}$ & $\mathbf{4 0}$ & $0.49^{\mathrm{A}}$ \\
Kontrol & 1.07 & 0.49 & 0.45 & 0.23 & 0.24 & $1.41^{\mathrm{C}}$ \\
Kedelai & 2.43 & 1.54 & 1.33 & 0.74 & 0.99 & $0.74^{\mathrm{B}}$ \\
Pisang & 1.15 & 1.03 & 0.63 & 0.49 & 0.40 & $0.76^{\mathrm{B}}$ \\
Tapioka & 1.27 & 0.93 & 0.76 & 0.30 & 0.50 & $0.54^{\mathrm{A}}$ \\
\hline \hline Rata-rata & $1.48^{\mathrm{D}}$ & $0.99^{\mathrm{C}}$ & $0.79^{\mathrm{B}}$ & $0.44^{\mathrm{A}}$ & \\
\hline \hline
\end{tabular}

Keterangan: angka yang diikuti huruf yang sama tidak beda nyata pada taraf kepercayaan 95\%

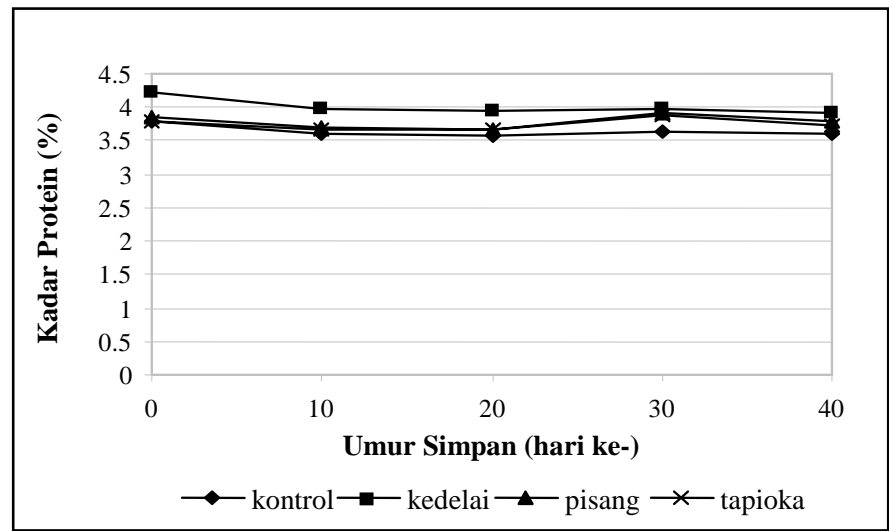

Gambar 4. Kadar protein (\%) yogurt probiotik dengan variasi jenis prebiotik selama masa simpan

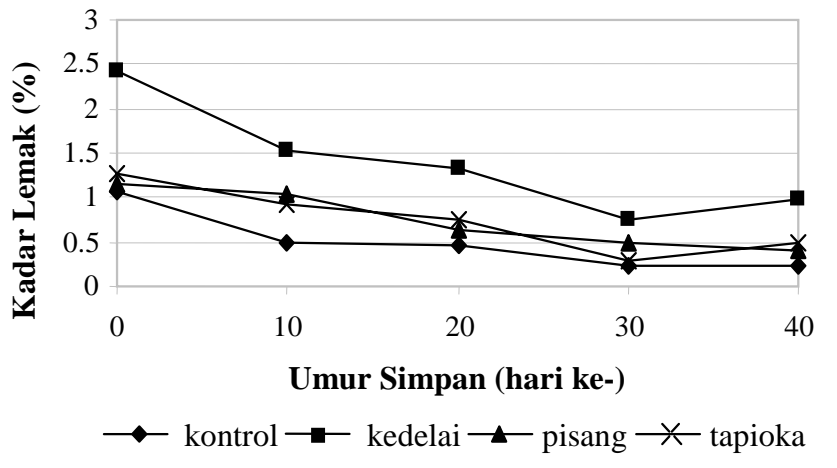

Gambar 5. Kadar lemak (\%) yogurt probiotik dengan variasi jenis prebiotik selama masa simpan 


\section{Kadar serat}

Kadar serat kasar pada yogurt probiotik berkisar antara 0.57 - 1.197\% (Tabel 6). Kadar serat tertinggi terdapat pada yogurt probiotik yang ditambahkan tepung kedelai. Hal tersebut disebabkan karena kedelai mengandung serat paling tinggi yakni sebanyak 2.8\% (Ngantung, 2003), sedangkan menurut Susilowati (2005), tepung pisang hanya mengandung serat $0.33 \%$ dan tepung tapioka mengandung $0.3 \%$ serat.

Nilai serat kasar berfluktuasi selama masa simpan (Gambar 6). Hal tersebut disebabkan $L$. acidophilus dapat menghasilkan selubung polisakarida pada lapisan terluar selnya yang disebut eksopolisakarida. Fungsi dari lapisan selain untuk pertahanan diri, juga dapat digunakan sebagai cadangan makanan pada saat kondisi nutrisi yang buruk (Widodo, 2003). Diduga pada saat pengukuran kadar serat, lapisan tersebut dapat terukur, sehingga kadar serat pada yogurt probiotik berfluktuasi.

\section{Analisis mikroorganisme pencemar yogurt Coliform}

Hasil uji Coliform menunjukkan bahwa yogurt probiotik kontrol dan yogurt probiotik dengan penambahan tepung pisang serta tepung tapioka masih memenuhi syarat mutu SNI yaitu kurang dari $3(<3)$ APM, sedangkan yogurt probiotik dengan penambahan tepung kedelai tidak memenuhi syarat karena mengandung coliform sebesar 18.53 APM (Tabel 7). Besarnya kandungan coliform tersebut dapat disebabkan karena kualitas air yang digunakan untuk merendam kedelai pada saat pembuatan tepung kurang baik.

Tabel 6. Perubahan kadar serat (\%) yogurt probiotik dengan variasi jenis prebiotik selama masa simpan

\begin{tabular}{ccccccc}
\hline \hline \multirow{2}{*}{ Jenis Prebiotik } & \multicolumn{9}{c}{ Umur Simpan (Hari Ke-) } & \multirow{2}{*}{ Rata-rata } \\
\cline { 2 - 6 } & $\mathbf{0}$ & $\mathbf{1 0}$ & $\mathbf{2 0}$ & $\mathbf{3 0}$ & $\mathbf{4 0}$ & $0.76^{\mathrm{A}}$ \\
\hline \hline Kontrol & 0.57 & 0.67 & 0.67 & 0.93 & 0.95 & $1.45^{\mathrm{C}}$ \\
Kedelai & 1.19 & 1.73 & 1.67 & 1.43 & 1.22 & $1.17^{\mathrm{BC}}$ \\
Pisang & 0.83 & 1.40 & 1.03 & 1.57 & 0.87 & $1.07^{\mathrm{B}}$ \\
Tapioka & 0.73 & 1.03 & 1.03 & 1.72 & 0.85 & $1.01^{\mathrm{A}}$ \\
\hline \hline Rata-rata & $0.83^{\mathrm{A}}$ & $1.21^{\mathrm{AB}}$ & $1.10^{\mathrm{AB}}$ & $1.41^{\mathrm{B}}$ & 1.20 \\
\hline \hline
\end{tabular}

Keterangan: angka yang diikuti huruf yang sama tidak beda nyata pada taraf kepercayaan 95\%.

Tabel 7. Jumlah bakteri coliform (APM) yogurt probiotik dengan variasi jenis prebiotik

\begin{tabular}{cc}
\hline \hline Jenis Prebiotik & Bakteri Coliform (APM) \\
\hline \hline Kontrol & $<0.3$ \\
Kedelai & 18.53 \\
Pisang & 1.17 \\
Tapioka & $<0.3$ \\
\hline \hline
\end{tabular}

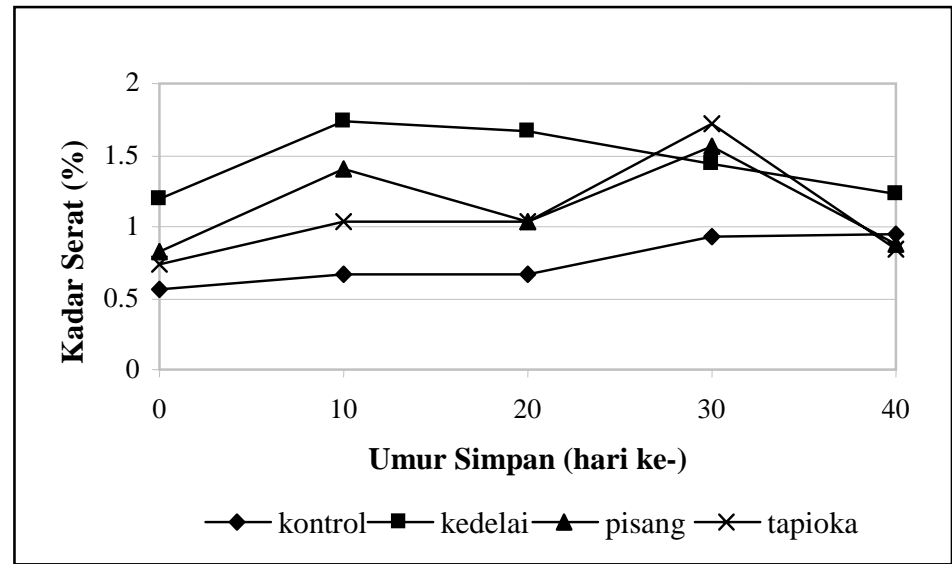

Gambar 6. Kadar serat (\%) yogurt probiotik dengan variasi jenis prebiotik selama masa simpan 
Keberadaan bakteri coliform merupakan indikator adanya polusi kotoran dan kondisi sanitasi yang tidak baik terhadap air dan bahan pangan. Pada proses pembuatan tepung kedelai, pengeringan pada suhu $60^{\circ} \mathrm{C}$, sehingga diduga bakteri coliform yang berasal dari air yang digunakan dalam perendaman kedelai tetap bertahan hidup.

\section{Bakteri Salmonella}

Hasil uji Salmonella menunjukkan bahwa tidak ada Salmonella pada semua sampel yogurt probiotik. Akumulasi asam laktat akan menyebabkan kenaikan keasaman atau penurunan $\mathrm{pH}$. Kondisi asam tinggi atau $\mathrm{pH}$ rendah akan menghambat pertumbuhan bakteri pembusuk ataupun bakteri patogen (Rahayu, 2004). Menurut Widodo (2003), aktivitas antimikroba dari bakteri asam laktat berkaitan dengan adanya asam organik (asam laktat, asam asetat dan asam format), hidrogen peroksida dan bakteriosin yang dihasilkan.

\section{Uji organoleptik}

Uji organoleptik dilakukan untuk mengetahui tingkat penerimaan konsumen terhadap aroma, warna dan tekstur yogurt probiotik. Yogurt adalah produk pangan hasil fermentasi susu yang mempunyai cita rasa khas. Kandungan asam pada yogurt cukup tinggi. Yogurt mempunyai tekstur semi padat dengan cita rasa segar sebagai akibat dihasilkannya berbagai komponen volatil penentu flavor seperti diasetil dan asetaldehid (Widodo, 2003).

Yogurt probiotik yang dihasilkan dinilai memiliki aroma terlalu asam. Hal tersebut karena kultur bakteri yang digunakan sebanyak 3 bakteri yaitu: L. bulgaricus, L. acidophilus dan S. thermophilus sehingga asam laktat yang dihasilkan juga semakin banyak.

Panelis lebih menyukai aroma yogurt dengan penambahan tepung tapioka (Tabel 8), karena aroma pada yogurt probiotik dengan penambahan tepung tapioka tidak terlalu asam. Hal tersebut karena asam laktat yang terbentuk lebih sedikit. Aroma yang paling tidak disukai yakni yogurt probiotik dengan penambahan tepung kedelai. Hal tersebut disebabkan karena aroma asam yang dihasilkan bercampur dengan aroma kedelai sehingga yogurt yang dihasilkan memiliki aroma seperti tahu.

Warna yogurt probiotik yang disukai panelis adalah yogurt probiotik dengan penambahan tepung tapioka karena yogurt tersebut berwarna lebih putih dibandingkan yogurt probiotik lainnya. Yogurt dengan penambahan tepung kedelai dan tepung pisang tidak disukai panelis, disebabkan karena tepung kedelai berwarna kuning kecoklatan sedangkan tepung pisang berwarna coklat.

Panelis lebih menyukai tekstur yogurt probiotik yang ditambah tepung tapioka karena tekstur semi solid yang homogen, sedangkan yang tidak disukai adalah yogurt probiotik dengan penambahan tepung kedelai. Pada penambahan tepung kedelai, yogurt probiotik tidak bisa menyatu secara keseluruhan antara bagian yang semi solid dengan bagian tepung kedelai. Bagian yang bersifat semi solid berada pada lapisan atas sedang tepung kedelai yang ditambahkan berada pada lapisan bawah dari yogurt probiotik yang dihasilkan.

\section{Kesimpulan}

Jenis prebiotik berpengaruh terhadap kualitas yogurt probiotik dan viabilitas bakteri asam laktat selama masa simpan. Tepung kedelai paling berpotensi meningkatkan nilai gizi dan viabilitas bakteri asam laktat pada yogurt probiotik, tetapi berdasarkan uji organoleptik, pemberian tepung tapioka pada yogurt probiotik lebih disukai panelis.

Tabel 8. Hasil uji organoleptik yogurt probiotik dengan variasi jenis prebiotik

\begin{tabular}{cccc}
\hline \hline Jenis Prebiotik & Aroma & Warna & Tekstur \\
\hline \hline Kontrol & 2.34 & 2.70 & 2.46 \\
Kedelai & 1.66 & 2.13 & 2.13 \\
Pisang & 2.33 & 2.17 & 2.63 \\
Tapioka & 2.63 & 3.10 & 2.90 \\
\hline \hline
\end{tabular}




\section{Ucapan Terima Kasih}

Peneliti mengucapkan terima kasih kepada Direktorat Jenderal Pendidikan Tinggi, Departemen Pendidikan Nasional yang telah memberikan dukungan dana melalui Proyek Penelitian Dosen Muda Tahun Anggaran 2007. Penghargaan juga disampaikan kepada Sdri. Christianti Haria dan Sdri. Valentina Vonny Manolong yang telah membantu proses penelitian, serta Sdr. A. Wisnu Tresno W untuk dukungan teknis saat penelitian.

\section{Daftar Pustaka}

Anonim. 1992. Standar Nasional Indonesia Yogurt, Pusat Standarisasi Departemen Perindustrian, Jakarta.

AOAC. 1990. Official Methods of Analysis $15^{\text {th }}$ ed. Association of Official Analytical Chemists, Washington DC.

Anggorodi, R. 1979. Ilmu Makanan Ternak Umum. PT Gramedia Pustaka Utama, Jakarta.

Budiharta, S. 1992. Hygiene Susu. PAU Pangan dan Gizi, Universitas Gadjah Mada, Yogyakarta.

Buckle, K.A., Edwards, R.A., Fleet, G.H. dan Wootton, M. 1987. Ilmu Pangan. Diterjemahkan oleh Adiono, H.P. UI-Press, Jakarta.

Dave, R.I. and Shah, N.P. 1997. Viability of yogurt and probiotics bacteria in yogurt made from commercial starter cultures. Int. Diary Jour. 7: 31-41.

Fooks, L.J., Fuller, R. and Gibson, G.R. 1999. Prebiotics, Probiotics and Human Gut Microbiology. Probiotica 9: 2-7.

Gilliand, S.E. 1985. Bacterial Starter Culture. CRC Press inc., Florida.

Kartika, B., Hastuti, P. dan Supartono, W. 1987. Pedoman Uji Inderawi Bahan Pangan. PAU Pangan dan Gizi Universitas Gadjah Mada, Yogyakarta.

Murti, T.W. 2006. Yogurt dan Daya Terima Konsumen. Food Review 1 (8): 24-26.

Ngantung, M. 2003. Pengaruh Penambahan Tepung Kedelai pada Tepung Terigu terhadap Nilai Gizi Mie Basah yang Dihasilkan. J. Sains \& Teknologi 3 (3): 110-118.
Rahayu, E.S. 2003. Uji Mikrobiologi Pada Bahan Makanan. Fakultas Teknologi Pertanian Universitas Gadjah Mada, Yogyakarta.

Rahayu, E.S. 2004. Kursus Singkat Pembuatan Yogurt. PAU Pangan \& Gizi Universitas Gadjah Mada, Yogyakarta.

Salminen, S. and Wright, A.V. 1993. Lactic Acids Bacteria. Marcel Dekker, New York.

Sudarmadji, S., Haryono, B. dan Suhardi. 1989. Prosedur Analisa untuk Bahan Makanan dan Pertanian. Liberty, Yogyakarta.

Suseno, T.I.P., Surjoseputro, S. dan Anita, K. 2000. Minuman Probiotik Nira Siwalan: Kajian Lama Penyimpanan terhadap Daya Anti Mikroba Lactobacillus casei pada Beberapa Bakteri Patogen. J. Teknologi Pangan \& Gizi 1 (1): 1-13.

Susilawati. 2005. Pengaruh Substitusi Pisang Uter (Musa paradisiaca forma tipica L.) pada Tepung Terigu Terhadap Sifat Fisikokimia Roti Tawar. Skripsi Fakultas Biologi, Universitas Atma Jaya, Yogyakarta.

Tamime, A.Y. and Deeth, H.C. 1989. Yogurt Technology and Biochemistry. J. Food Protection 43 (12): 937-977.

Triana, E. dan Nurhidayat, M. 2007. Seleksi dan Identifikasi Lactobacillus Kandidat Probiotik Penurun Kolesterol Berdasarkan Analisis Sekuen 16S RNA. Biota 12 (1): 55-60.

Waspodo, I.S. 2002. Efek Probiotik, Prebiotik dan Symbiotik Bagi Kesehatan. Bull. Food \& Beverage Industry $4^{\text {th }}$.

Widodo dan Soeparno. 2002. Pendayagunaan Tepung Terigu Sebagai Prebiotik dan Bioenkapsulator untuk Peningkatan Viabilitas Probiotik Selama Fermentasi dan Penyimpanan. Universitas Gajah Mada, Yogyakarta.

Widodo. 2003. Bioteknologi Pengolahan Susu. Lacticia Press, Yogyakarta.

Yusmarini, Adnan, M. dan Hadiwiyoto, S. 1998. Perubahan Oligosakarida pada Susu Kedelai dalam Proses Pembuatan Yogurt. BPPSUniversitas Gadjah Mada 11 (1B): 59-69. 